\title{
ANALISA PEMANFAATAN KOMPOS SEBAGAI MEDIA BIOCOVER DI TEMPAT PEMROSESAN AKHIR SAMPAH: STUDI KASUS KOTA DEPOK, JAWA BARAT
}

\author{
Gabriel Andari Kristanto*), Dwi Rahayu, dan Evy Novita \\ Program Studi Teknik Lingkungan, Departemen Teknik Sipil \\ Fakultas Teknik, Universitas Indonesia \\ Kampus Baru UI Depok, 16424, Indonesia \\ ${ }^{*}$ Penulis korespondensi: gakristanto@gmail.com
}

\begin{abstract}
ANALYSIS OF COMPOST UTILIZATION AS BIOCOVER MEDIA IN LANDFILL: A CASE STUDY IN DEPOK, WEST JAVA, INDONESIA. The high percentage of organic waste in urban areas makes composting a good alternative in waste processing. However, composting has not been effectively used and unfortunately, the results have been less than optimal. Previous studies have found that compost can be used as biocover media to reduce landfill methane emissions. The objective of the study is to identify the characteristic of produced at temporary waste unit Depok, West Java and the effect of compaction toward the amount of methane removal in the landfill. Before applied as biocover media, compost was characterized followed by maturation process. Study on methane removal efficiency was conducted in four reactors for 35 days with compaction rate varying from 750 , 800,850 dan $900 \mathrm{~kg} / \mathrm{m}^{3}$. Composting media used in the research had $80 \mathrm{~cm}$ thickness with artificial gas consisting of 50\% $\mathrm{CH}_{4}$ dan $50 \% \mathrm{CO}_{2}$. Initially, compost did not meet criteria as mature compost based on SNI 19-7030-2004, hence a pre-treatment was needed to improve the compost quality to meet the requirements. Compaction rate of $900 \mathrm{~kg} / \mathrm{m}^{3}$ has highest elimination capacity of methane i.e. $98.31 \pm 0.036 \%$ and $13.98 \pm 4.32 \mathrm{~g} / \mathrm{m}^{3} /$ hour respectively.
\end{abstract}

Keywords : compaction; compost; methane; waste processing landfill

\begin{abstract}
Abstrak
Tingginya komposisi sampah organik perkotaan memungkinkan pengomposan menjadi alternatif pilihan pengolahan, namun sampai saat ini pemanfaatan kompos tersebut belum optimal. Salah satu pemanfaatan kompos adalah sebagai media biocoveruntuk mengurangi emisi gas metana di Tempat Pemrosesan Akhir (TPA). Tujuan penelitian adalah untuk mengetahui potensi pemanfaatan kompos yang diproduksi di Depok sebagai media biocover. Pada tahap awal penelitian dilakukan karakterisasi kompos secara fisik, kimia dan biologi. Tahap berikutnya adalah menganalisa efisiensi penyisihan metana yang dilakukan dalam empat reaktor secara batch selama 35 hari dengan variasi pemadatan 750, 800, 850 dan $900 \mathrm{~kg} / \mathrm{m}^{3}$. Ketinggian media kompos $80 \mathrm{~cm}$ dan komposisi gas emisi buatan $50 \% \mathrm{CH}_{4}$ dan $50 \% \mathrm{CO}_{2}$. Pemeriksaan awal menunjukkan bahwa kompos belum memenuhi kriteria sebagai kompos matang sesuai dengan SNI 19-7030-2004 dan sebagai media biocover sehingga diperlukan pengolahan pendahuluan guna meningkatkan kualitas kompos tersebut. Pemadatan $900 \mathrm{~kg} / \mathrm{m} 3$ memiliki kemampuan penyisihan dan kapasitas eliminasi metana tertinggi yaitu $98,31 \pm 3,6 \%$ dan $13,98 \pm 4,32 \mathrm{~g} / \mathrm{m}^{3} / \mathrm{jam}$ serta potensi penyumbatan yang lebih rendah.
\end{abstract}

Kata kunci : pemadatan; kompos; metana; tempat pemrosesan akhir sampah

How to Cite This Article: Kristanto, G.A., Rahayu, D., dan Novita, E., (2014), Analisa Pemanfaatan Kompos sebagai Media Biocover di Tempat Pemrosesan Akhir Sampah: Studi Kasus Kota Depok, Jawa Barat, Reaktor, 15(2), 117-125, http://dx.doi.org/10.14710/reaktor.15.2.117-125

\section{PENDAHULUAN}

Banyaknya sampah yang dihasilkan di perkotaan yang didominasi oleh sampah organik menyebabkan berbagai pencemaran di lingkungan sekitar tempat pemrosesan akhir sampah (TPA) seperti pencemaran air tanah dan udara (Burton dan Craik., 
1998; Huber-Humer dkk., 2009, Tchobanoglous dan Kreith, 2002). Secara umum pencemaran udara di TPA dapat disebabkan oleh emisi berbagai jenis gas yang biasa dikenal sebagai LFG (Landfill Flue Gas) seperti metana, karbon dioksida, hidrogen sulfida dan berbagai pencemar udara organik. Metana dan karbondioksida merupakan pencemar gas utama yang diemisikan dari dekomposisi fraksi organik dari limbah padat (Tchobanoglous dkk., 1993). Gas metana secara alami merupakan gas yang mudah terbakar, tidak berwarna, tidak berbau, dan bersifat eksplosif. Sebagai salah satu gas rumah kaca, metana perlu dikurangi emisinya karena menimbulkan dampak negatif terhadap lingkungan dengan potensi 20 kali lebih besar dibandingkan karbon dioksida (IPCC, 2000).

Sebagai sebuah kota penyangga Jakarta, Depok menghadapi banyak persoalan persampahan. Lebih dari $70 \%$ produksi sampah Depok sebesar 3200 ton/hari dibuang ke TPA Cipayung sehingga diemisikan metana sebesar 4 juta $\mathrm{kg}$ pada tahun 2013 ( $\mathrm{Ng}$ dan Kristanto, 2013). Berbagai cara dilakukan untuk mengendalikan beban sampah yang semakin besar di TPA Cipayung, salah satunya adalah dengan mengoptimalisasikan pengelolaan TPA dan meningkatkan pelaksanaan pada seluruh kegiatan 3R$\mathrm{P}$ (Reduce, Reuse, Recycle, and Participation) (Dinas Kebersihan dan Pertamanan Kota Depok, 2012). Pengomposan didorong oleh Pemerintah Daerah Depok dengan dibangunnya 30 buah Unit Pengolah Sampah (UPS) di berbagai lokasi. Sebagian besar Unit Pengolah Sampah tersebut sudah memproduksi kompos namun belum dapat termanfaatkan karena adanya berbagai kendala seperti proses produksi kompos yang masih belum sempurna, kemungkinan kontaminasi pencemar terhadap bahan baku, keterbatasan pengetahuan, dan rendahnya pemasaran.

Salah satu teknologi pemanfaatan kompos yang saat ini banyak dikembangkan adalah kompos sebagai media biocover (Huber-Humer dkk., 2009; Mosafid dkk., 2012; Scheutz dkk., 2009). Pemanfaatan kompos sebagai media biocover banyak dikembangkan di berbagai negara maju, tetapi sayangnya belum pernah diterapkan di Indonesia. Tingginya komposisi sampah organik di Indonesia serta pengomposan, memungkinkan teknologi kompos sebagai media biocover dapat dimanfaatkan di banyak TPA. Biocover atau disebut juga biofilter merupakan material penyaring pencemar udara yang didasarkan pada kemampuan mikroorganisme pada medium berpori untuk mendegradasi pencemar. Selama proses penyaringan berlangsung, mikroorganisme tumbuh pada permukaan media biofilter dan membentuk biofilm. Media biofilter dapat berasal dari substansi inert, seperti kompos, peat, dan lain-lain. Pada saat pencemar melewati media filter dalam kondisi aerobik, mikroba kemudian mengubahnya menjadi karbondioksida, air serta biomassa. Berbagai faktor mempengaruhi efektivitas pengurangan pencemar melalui proses biofilter seperti ketebalan biofilm, jenis dan pemadatan media biofilter, nutrisi, $\mathrm{pH}$, mikroorganisme, tingkatan oksigen, kandungan air, dan temperatur (Kumar dkk., 2011).

Secara umum lapisan penutup pada TPA terdiri atas lapisan subbase, barrier, protective, dan surface (Tchobanoglous dkk., 1993). Lapisan subbase digunakan untuk kontur permukaan TPA dan berfungsi sebagai lapisan penghalang. Lapisan barrier digunakan untuk membatasi perpindahan cairan masuk ke TPA dan pelepasan gas TPA melalui penutup. Lapisan drainase digunakan untuk media perkolasi air hujan dan menjauh dari lapisan barrier dan untuk mengurangi tekanan air pada lapisan barrier. Lapisan pelindung (protective layer) merupakan lapisan untuk melindungi lapisan drainase dan barrier. Lapisan permukaan (surface layer) digunakan untuk membentuk permukaan dan untuk mendukung desain TPA sehingga dapat digunakan dalam waktu lama (Tchobanoglous dan Kreith, 2002). Media biofilter pada umumnya ditempatkan di atas surface layer pada TPA dengan tingkat pemadatan serupa dengan pemadatan sampah (Permen PU, 2013). Penempatan media biocover terutama dilakukan di TPA yang tidak memiliki sistem pengontrolan emisi, TPA yang sudah tua atau TPA kecil yang jumlah emisi metananya tidak lagi ekonomis untuk digunakan sebagai sumber energi terbarukan (Huber-Humer dkk., 2009).

Tujuan penelitian ini adalah untuk mengkarakterisasi kompos yang dihasilkan di Depok serta potensinya sebagai media biocover. Emisi metana yang cukup besar di TPA Cipayung serta tidak adanya sistem pengontrolan emisi gas menyebabkan teknologi pemanfaatan kompos sebagai biocover menjadi sangat potensial. Empat variasi pemadatan digunakan selama penelitian untuk mendapatkan kondisi optimal dalam pengurangan emisi metana di TPA.

\section{METODE PENELITIAN \\ Alat dan Bahan}

Penelitian ini adalah penelitian kuantitatif dengan metode eksperimen dengan menggunakan empat reaktor biofilter (R1, R2, R3, dan R4). Variabel bebas pada penelitian ini adalah variasi pemadatan pada setiap reaktor biofilter (pada laboratorium) dan variabel terikat adalah efisiensi pengurangan gas metana yang dihasilkan dan kapasitas eliminasi gas metana.

Kompos yang digunakan adalah kompos sudah matang dengan mengacu pada SNI No19-7030-2004 serta persyaratan kompos sebagai media biocover (Huber-Humer dkk., 2009). Karakteristik fisik kompos yang diuji adalah kandungan air, kemampuan ikat air, porositas, temperatur, warna dan bau, dan ukuran butiran. Metode pengujian untuk parameter fisik mengikuti ASTM (American Society for Testing and Materials), dan beberapa parameter lain seperti warna dan bau diuji melalui organoleptik. Karakteristik kimia yang diuji adalah konduktivitas dan $\mathrm{pH}, \mathrm{SO}_{4}{ }^{2-}$, 
Fe, $\mathrm{Mn}, \mathrm{NH}_{3}-\mathrm{N}, \mathrm{NH}_{4}{ }^{+}-\mathrm{N}, \mathrm{NO}_{3}{ }^{-}-\mathrm{N}, \mathrm{N}$ Total, $\mathrm{PO}_{4}-\mathrm{P}$ atau $\mathrm{P}$ total, $\mathrm{C}$-Organic, $\mathrm{C} / \mathrm{N}$, ignition Loss, serta kandungan logam yaitu $\mathrm{Cd}, \mathrm{Zn}, \mathrm{Cr}, \mathrm{Cu}$, dan $\mathrm{Pb}$. Metoda pengujian karakteristik kimia ini menggunakan acuan yang sebagian besar berasal dari metoda standard (American Public Health Association, 2012). Karakteristik biologis yang diuji adalah enumerasi mikroba dan fecal coli. Enumerasi mikroba diuji dengan menggunakan metoda standard Total Plate Count (TPC) dan fecal coli diuji dengan menggunakan metoda standard Multiple Tube Fermentation (MTF). Pada penelitian ini dilakukan juga pemadatan pada kompos dengan empat variasi pemadatan yaitu $750,800,850$, dan $900 \mathrm{~kg} / \mathrm{m}^{3}$.

Reaktor biofilter yang digunakan terbuat dari bahan acrylic dengan ketebalan $5 \mathrm{~mm}$, diameter luar sebesar $20 \mathrm{~cm}$, dan tinggi $1 \mathrm{~m}$. Lapisan pertama pada reaktor merupakan kerikil yang dapat berfungsi sebagai lapisan distribusi gas. Tinggi lapisan kerikil pada reaktor ini adalah $5 \mathrm{~cm}$. Ukuran kerikil yang digunakan berdiameter 30-60 mm. Ukuran ini sesuai dengan ukuran lapisan kerikil yang digunakan sebagai penutup akhir pada sistem sanitary landfill ataupun controlled landfill. Lapisan setelah kerikil merupakan lapisan kompos. Tinggi media kompos ini adalah 80 $\mathrm{cm}$. Tinggi media ini merepresentasikan tinggi lapisan final cap pada landfill, baik sanitary landfill maupun controlled landfill, yaitu minimal sebesar $60 \mathrm{~cm}$ (Damanhuri dkk., 2006). Reaktor ditutup dengan menggunakan acrylic penutup yang tebalnya $9 \mathrm{~mm}$ dan diperkuat dengan menggunakan baut yang terbuat dari baja.

Gas yang digunakan pada penelitian ini merupakan gas artifisial yang dibuat dengan rasio volume $\mathrm{CH}_{4}: \mathrm{CO}_{2}$ sebesar 50\%:50\%. Perbandingan ini merupakan perbandingan gas artifisial yang disesuaikan dengan persentase gas yang dominan di landfill. Sistem aliran gas pada biofilter ini adalah sistem upflow, dimana gas mengalir dari bawah ke atas permukaan media dan ditampung dengan menggunakan gas bag. Udara yang dialirkan ke dalam reaktor merupakan udara yang bertekanan dari campuran gas (dari tabung gas) dan udara yang berasal dari kompresor. Sebelum gas masuk ke dalam reaktor, gas terlebih dahulu melewati humidifier yang berfungsi untuk menjaga kelembaban gas sehingga memperkecil terjadinya penurunan kandungan air pada media filter. Aerasi dilakukan dengan mengalirkan udara dari kompresor yang melalui humidifier menuju bagian atas reaktor yang tidak diisi media filter. Aerasi berfungsi untuk mempertahankan konsentrasi oksigen pada reaktor sesuai dengan kondisi atmosfer pada biocover landfill dan mencegah terjadinya kondisi anaerobik selama masa operasional biofilter. Leachate yang dihasilkan selama operasional dikeluarkan melalui katup yang terletak pada bagian bawah reaktor (Gambar 1).

Pengukuran konsentrasi dan volume gas $\mathrm{CH}_{4}$ dan $\mathrm{CO}_{2}$ dilakukan pada inlet dan outlet. Waktu pengaliran gas didasarkan pada nilai bed true residence time setiap reaktor, dengan persamaan berikut:

$$
\tau=\frac{v \times \theta}{Q}
$$

Dimana:

$\tau=$ true residence time $(\mathrm{jam})$

$\mathrm{v}=$ Volume filter $\left(\mathrm{m}^{3}\right)$

$\theta=$ Porositas (Volume pori/volume media filter)

$\mathrm{Q}=\operatorname{Debit}\left(\mathrm{m}^{3} / \mathrm{jam}\right)$

Pengaliran gas dilakukan selama 4 jam 30 menit dan gas metana yang keluar dari reaktor ditampung dalam gas bag kemudian diuji dengan Gas Chromatography (GC) antara 2-4 hari pengoperasian.

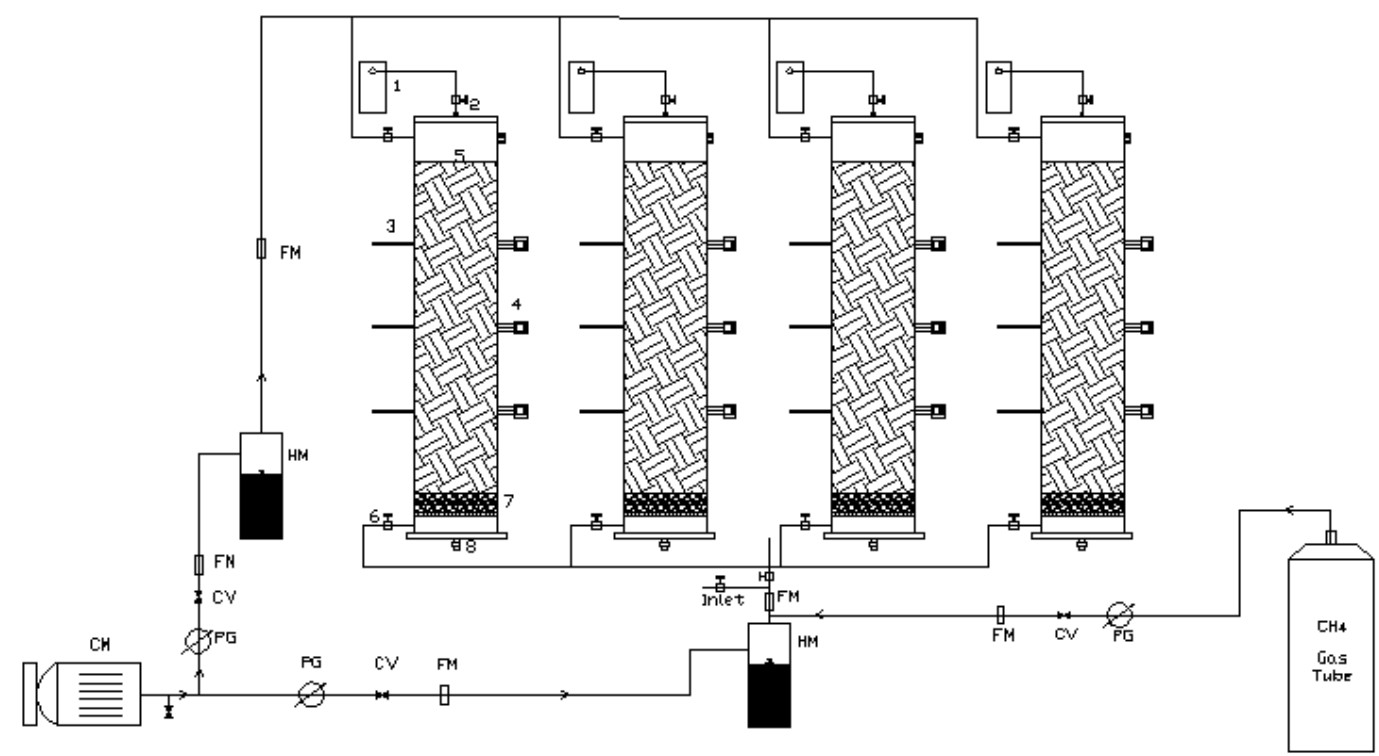

Keterangan : (1) gas bag, (2) efluen, (3) termometer, (4) pH meter, (5) kompos, (6) influen, (7) kerikil, (8) outlet lindi, cm: compressor, Fm: flow meter, Hm: Humidifier, Pg: Pressure Gauge

Gambar 1.Rangkaian reaktor biofilter 


\section{Pengolahan Data}

a. Produksi $\mathrm{CO}_{2} \quad\left(\mathrm{PCO}_{2}\right)$ dengan satuan: $\mathrm{g} / \mathrm{m}^{3} / \mathrm{h}$, dihitung dengan persamaan berikut:

$$
P \mathrm{CO}_{2}=\frac{\left(\mathrm{C}_{\mathrm{CO}_{2} \text { out }}-\mathrm{C}_{\mathrm{CO}_{2} \text { in }}\right) \times Q}{V}
$$

b. Efisiensi pengurangan gas metana (RE):

$$
R E=\left(\frac{C_{C_{i}}-C_{C_{o}}}{C_{C_{i}}}\right) \times 100
$$

c. Elimination Capacity (EC):

$$
E C=\frac{\left(C_{C_{1}}-C_{C_{o}}\right) \times Q}{V_{f}}
$$

Dimana:

$$
\begin{array}{ll}
\mathrm{C}\left(\mathrm{CO}_{2}\right) & =\text { konsentrasi gas } \mathrm{CO}_{2}\left(\mathrm{~g} / \mathrm{m}^{3}\right) \\
\mathrm{Q} & =\text { laju gas }\left(\mathrm{m}^{3} / \mathrm{jam}, \mathrm{m}^{3} / \mathrm{s}\right) \\
\mathrm{V} & =\text { volume media filter }\left(\mathrm{m}^{3}\right) \\
\mathrm{A} & =\text { luas filter }\left(\mathrm{m}^{2}\right) \\
\mathrm{C}_{\mathrm{Gi}} & =\text { konsentrasi inlet }\left(\mathrm{ppmv}, \mathrm{g} / \mathrm{m}^{3}\right) \\
\mathrm{C}_{\mathrm{Go}} & =\text { konsentrasi outlet }\left(\mathrm{ppmv}, \mathrm{g} / \mathrm{m}^{3}\right)
\end{array}
$$

\section{HASIL DAN PEMBAHASAN}

\section{Karakteristik Fisik, Kimia, dan Biologis Kompos}

Hasil pengujian karakteristik kompos UPS Depok ditampilkan pada Tabel 1. Secara fisik kompos produksi UPS Depok belum memenuhi standar sebagai kompos yang matang. Terlihat dari warna kompos yang kecoklatan, kering, dan kandungan air yang belum memenuhi (19,8\%). Pengolahan pendahuluan kemudian dilakukan hingga mencapai standard yang diinginkan sebagai kompos matang. Pada kompos matang, kadar air ditingkatkan untuk memungkinkan terjadinya aktivitas metabolik mikroorganisme guna memperbesar laju biodegradasi (Devinny dkk., 1999). Dari segi warna dan bau kompos juga sudah sesuai dengan standar yang diinginkan. Water Holding Capacity (WHC) atau daya ikat air merupakan kemampuan material dalam mengikat air yang berada pada material tersebut. Standar yang ditetapkan untuk WHC adalah 50-130\% dan WHC kompos ini memenuhi kriteria tersebut. Pada aplikasi sebagai media biocover, kompos diharapkan dapat pulamengurangi kuantitas air lindi pada landfill.

Nilai bulk density kompos juga meningkat setelah dilakukan pengolahan pendahuluan yaitu dari semula 229,88 $\mathrm{kg} / \mathrm{L}$ menjadi 809,86 $\mathrm{kg} / \mathrm{L}$. Peningkatan bulk density ini terjadi karena adanya penambahan air yang dilakukan selama proses pematangan kompos. Peningkatan juga terjadi karena adanya proses pengayakan kompos (lolos saringan
No.10 atau $<2 \mathrm{~mm}$ ) sehingga ukuran butiran kompos menjadi lebih kecil dan seragam. Hasil pengujian karakteristik kimia kompos produksi UPS Depok ditampilkan pada Tabel 2.

Secara umum, beberapa parameter kimia kompos sebelum dan sesudah dilakukan pengolahan pendahuluan telah memenuhi acuan yang telah ditetapkan sebelumnya, namun ada juga beberapa parameter yang tidak sesuai dengan nilai acuan yang diharapkan. Konduktivitas kompos sebesar 16,54 $\mathrm{mS} / \mathrm{cm}$. Angka ini cukup tinggi jika dibandingkan acuan kompos yang baik untuk media biocover namun sesungguhnya memberikan pengaruh kecil pada kinerja oksidasi (Figueroa, 1993; Abichou dkk., 2009; Huber-Humer dkk., 2009). Beberapa penelitian sebelumnya juga mengukur konduktivitas bersamaan dengan faktor lain dalam material biocover dan biofilter seperti $\mathrm{pH}$ dan kandungan nitrogen (Streese dan Stegmann, 2003; Mor dkk., 2006; Philopoulos dkk., 2009). pH kompos sebelum dan sesudah pengolahan pendahuluan tidak jauh berbeda yaitu 7,6 dan 7,5. Menurut rekomendasi Huber-Humer dkk., (2009), nilai pH pada kompos yang akan digunakan sebagai media biocover harus berada pada kisaran 6,58,5. Nilai ini merupakan nilai $\mathrm{pH}$ yang mendekati netral yang menandakan bahwa terdapat bakteri methanotroph dalam kompos tersebut. Kandungan sulfat yang terdapat pada kompos juga akan mempengaruhi oksidasi metana. Berdasarkan Tabel 2, nilai sulfat sudah sesuai dengan kandungan sulfat yang diinginkan, yaitu $>500$. Dengan nilai sulfat yang tinggi, maka kompos ini tidak hanya bisa digunakan dalam kondisi aerobik, melainkan juga dapat digunakan saat terjadi kondisi anaerobik.

Parameter berikutnya yang mempengaruhi oksidasi metana adalah beberapa bentuk nitrogen, seperti: amonium, nitrat, dan nitrit. Menurut HuberHumer dkk., (2009), amonium dan nitrit merupakan inhibitor (penghambat) dalam oksidasi metana. Pada penelitian ini, didapatkan nilai amonium yang telah sesuai dengan standar yang diinginkan yaitu $<400$ ppm DM. Pada penelitian ini juga terjadi pengurangan amonium selama proses pematangan. Pada awalnya, kompos memiliki kandungan amonium sebesar 132,46 ppm DM dan 80,51 ppm DM setelah kompos mengalami pengolahan pendahuluan berupa proses pengadukan dan penambahan air pada kompos, sehingga amonia ternitrifikasi menjadi $\mathrm{NO}_{2}{ }^{-}$atau $\mathrm{NO}_{3}$.

Tabel 1. Hasil pengujian karakteristik fisik kompos

\begin{tabular}{lccccc}
\hline \multicolumn{1}{c}{ Parameter } & Satuan & $\begin{array}{c}\text { Kompos } \\
\text { pretreatment }\end{array}$ & $\begin{array}{c}\text { Kompos } \\
\text { Matang }\end{array}$ & Nilai Acuan & Sumber Acuan \\
\hline $\begin{array}{l}\text { Bulk density } \\
\text { Kadar air }\end{array}$ & $\mathrm{kg} / \mathrm{L}$ & 229,88 & 809,86 & $800-1100$ & Huber-Humer dkk. (2009) \\
Water holding & \%w/w & 19,8 & 49,15 & $30-50$ & Huber-Humer dkk. (2009) \\
capacity (WHC) & $\% \mathrm{DM}$ & 57,5 & 60 & $50-130$ & Huber-Humer dkk. (2009) \\
Ukuran Partikel & $\mathrm{mm}$ & & $<2$ & $0,063-2$ & Huber-Humer dkk. (2009). \\
$\begin{array}{l}\text { Temperatur } \\
\text { Warna }\end{array}$ & ${ }^{\circ}$ & 27,5 & 29 & Maks: suhu air tanah & SNI 19-7030-2004 \\
Bau & & Kecoklatan & Hitam & Kehitaman & SNI 19-7030-2004 \\
\end{tabular}


Reaktor, Vol. 15 No. 2, Oktober 2014, Hal. 117-125

Tabel 2. Hasil pengujian karakteristik kimia kompos

\begin{tabular}{|c|c|c|c|c|c|}
\hline Parameter & Satuan & $\begin{array}{c}\text { Kompos sebelum } \\
\text { pengolahan }\end{array}$ & $\begin{array}{l}\text { Kompos } \\
\text { Matang }\end{array}$ & Nilai Acuan & Sumber Acuan \\
\hline Konduktivitas & $\mathrm{mS} / \mathrm{cm}$ & 22,20 & 16,54 & $<4$ & Huber-Humer dkk. (2009) \\
\hline $\mathrm{pH}$ & & 7,60 & 7,5 & $6.5-8.5$ & Huber-Humer dkk. (2009) \\
\hline $\mathrm{SO}_{4}^{2-}$ & ppm DM & 6215,50 & 4333,14 & $>500$ & Huber-Humer dkk. (2009) \\
\hline $\mathrm{NH}_{4}^{+}-\mathrm{N}$ & ppm DM & 132,46 & 80,51 & $<400$ & Huber-Humer dkk. (2009) \\
\hline $\mathrm{NO}_{2}{ }^{-} \mathrm{N}$ & ppm DM & 641,60 & 680,92 & $<0.1$ & Huber-Humer dkk. (2009) \\
\hline $\mathrm{NO}_{3}{ }^{-} \mathrm{N}$ & ppm DM & 1050,62 & 928,53 & $\begin{array}{c}\text { Tidak ada } \\
\text { batasan nilai }\end{array}$ & Huber-Humer dkk. (2009) \\
\hline Ptotal & $\% \mathrm{DM}$ & 5,33 & 0,84 & $>0.3$ & Huber-Humer dkk. (2009) \\
\hline Ntotal (Kjeldahl) & $\% \mathrm{DM}$ & 4,08 & 2,36 & $>0.5$ & Huber-Humer dkk. (2009) \\
\hline Loss of ignition & $\% \mathrm{DM}$ & 51,50 & 38,90 & $>15$ & Huber-Humer dkk. (2009) \\
\hline $\mathrm{C} / \mathrm{N}$ & & 6,59 & 7,42 & $0.2-20$ & SNI 19-7030-2004 \\
\hline Kadmium (Cd) & $\mathrm{mg} / \mathrm{kg}$ & 2,92 & 7,41 & 3 (maks) & SNI 19-7030-2004 \\
\hline Zink (Zn) & $\mathrm{mg} / \mathrm{kg}$ & 69,68 & 302,54 & 500 (maks) & SNI 19-7030-2004 \\
\hline Timbal $(\mathrm{Pb})$ & $\mathrm{mg} / \mathrm{kg}$ & 13,15 & 72,70 & 150 (maks) & SNI 19-7030-2004 \\
\hline Besi $(\mathrm{Fe})$ & $\mathrm{ppm}$ & 0,72 & 0,99 & $2 \%$ (maks) & SNI 19-7030-2004 \\
\hline Mangan (Mn) & ppm & 0,00 & 0,00 & $0.1 \%$ (maks) & SNI 19-7030-2004 \\
\hline Tembaga $(\mathrm{Cu})$ & $\mathrm{mg} / \mathrm{kg}$ & 119,72 & 140,24 & 100 (maks) & SNI 19-7030-2004 \\
\hline
\end{tabular}

Tabel 3. Hasil pengujian karakteristik biologis kompos

\begin{tabular}{lccccc}
\hline \multicolumn{1}{c}{ Parameter } & Satuan & Kompos pretreatment & $\begin{array}{c}\text { Kompos } \\
\text { Matang }\end{array}$ & Nilai Acuan & Sumber Acuan \\
\hline $\begin{array}{l}\text { Enumerasi } \\
\text { mikroba }\end{array}$ & CFU/mL & $4,98 \mathrm{E}+6$ & $4,00 \mathrm{E}+12$ & & SNI 19-7030-2004 \\
Fecal Coli & MPN/gr & 33,93 & 340 & 1000 (maks) & SNI 19-7030-2004 \\
\hline
\end{tabular}

Ini juga dapat terlihat dari kandungan $\mathrm{NO}_{2}^{-}$yang lebih tinggi pada kompos matang dibandingkan kompos sebelum diolah.

Nilai nitrat dan $\mathrm{N}$ total pada kompos lebih besar, yaitu $928,53 \mathrm{ppm}$ nitrat dan 2,36\% DM nilai $\mathrm{N}$ total. Berbeda dengan amonium dan nitrit, kandungan nitrat dan nilai $\mathrm{N}$ total merupakan parameter yang penting untuk bakteri methanotroph pada kompos. Bakteri methanotroph memiliki kebutuhan nitrogen dalam bentuk nitrat yang tinggi sebagai sumber nitrogen anorganik yang kemudian dimanfaatkan guna membentuk protein sebagai sumber pertumbuhan (Bodelier dan Laanbroek, 2004; Scheutzdkk., 2009). Rasio C/N kompos setelah pengolahan adalah 7,42. Nilai ini masih berada pada rentang yang ditentukan, yaitu 0,2-20.

Parameter logam diukur untuk memenuhi kriteria kompos matang yang ditetapkan SNI No 197030-2004, meskipun beberapa penelitian untuk kompos sebagai media biocover tidak memasukkan parameter ini dalam rekomendasinya (Huber-Humer dan Lechner, 2001). Semua parameter logam yang diuji telah memenuhi standar baku mutu yang ditetapkan.

Hasil pengamatan karakteristik biologis kompos produksi UPS Depok ditampilkan pada Tabel 3. Kompos yang matang memiliki jumlah mikroorganisme yang lebih banyak dibanding sebelumnya. Hal ini karena adanya penambahan air selama proses pematangan kompos. Kandungan air pada kompos dapat mendukung pertumbuhan populasi mikroorganisme di dalamnya.

\section{Pengaruh Pemadatan Terhadap Oksidasi Gas Metana}

Sebelum dilakukan pengujian, dilakukan aklimatisasi terhadap media biofilter selama satu minggu agar mikroorganisme mampu beradaptasi dengan kontaminan metana (Devinny dkk., 1999). Pada tahap tersebut tiap reaktor dialiri gas metana 5 $\mathrm{ml} / \mathrm{min}$ (atau $20 \mathrm{ml} / \mathrm{min}$ untuk keseluruhan) dan aliran dari kompresor sebesar $200 \mathrm{ml} / \mathrm{min}$. Rata-rata kompos membutuhkan waktu 3 hari untuk beradaptasi terhadap kehadiran metana. Hal ini terlihat dari Reaktor 1, 3, dan 4 (tingkat pemadatan 750, 850, dan $900 \mathrm{~kg} / \mathrm{m}^{3}$ ) yang memiliki kecenderungan penurunan metana setelah hari ketiga aklimatisasi. Berbeda dengan reaktor lainnya, selama tahap aklimatisasi konsentrasi gas metana pada outlet Reaktor 2 masih menunjukkan angka nol. Hal ini kemungkinan terjadi karena proses oksidasi gas metana pada Reaktor 2 belum terjadi karena adsorpsinya yang belum berlangsung.

Setelah tahap aklimatisasi dilakukan, penelitian dilanjutkan dengan menaikkan laju alir gas inlet 2 kali lipat dari yang sebelumnya (yaitu $40 \mathrm{ml} / \mathrm{min}$ ) dan dari kompresor sebesar $400 \mathrm{ml} / \mathrm{min}$. Kemudian, gas ini dialirkan merata ke empat reaktor. Gambar 2 dan 3 menampilkan profil konsentrasi gas metana dan karbondioksida selama waktu pengujian 35 hari.

Gambar 2 merupakan grafik konsentrasi gas metana yang terdeteksi di outlet untuk semua reaktor. Berdasarkan pengamatan diketahui bahwa konsentrasi gas inlet berkisar antara 29,13-82,63 g/m ${ }^{3}$, R1 (750 $\left.\mathrm{kg} / \mathrm{m}^{3}\right)$ antara $1,8-28,96 \mathrm{~g} / \mathrm{m}^{3}, \mathrm{R} 2\left(800 \mathrm{~kg} / \mathrm{m}^{3}\right)$ antara $0-16,14 \mathrm{~g} / \mathrm{m}^{3}$, R3 $\left(850 \mathrm{~kg} / \mathrm{m}^{3}\right)$ antara $0-13,54 \mathrm{~g} / \mathrm{m}^{3}$, dan R4 $\left(900 \mathrm{~kg} / \mathrm{m}^{3}\right)$ antara $0-6,04 \mathrm{~g} / \mathrm{m}^{3}$. Gas metana 


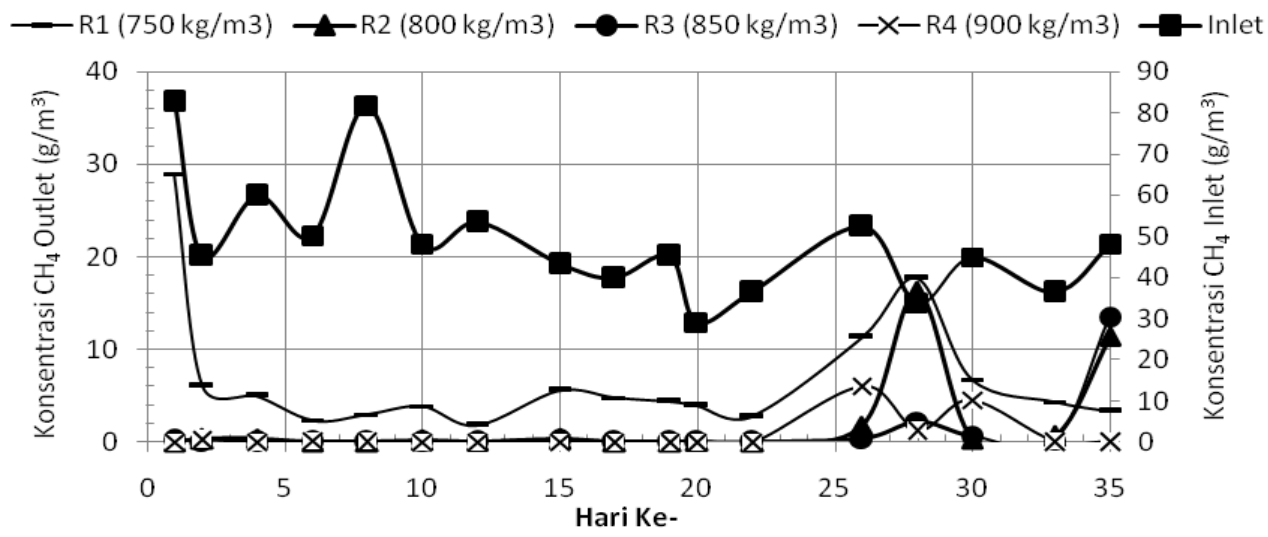

Gambar 2. Profil Konsentrasi Gas Metana

pada R2, R3, dan R4 telah menunjukkan konsentrasi yang rendah sejak awal penelitian, sedangkan R1 menunjukkan konsentrasi yang lebih tinggi dibandingkan reaktor lainnya.

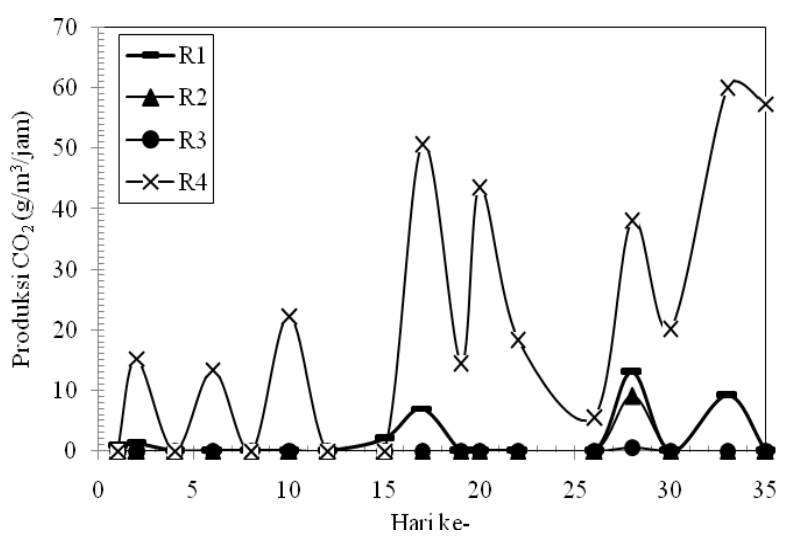

Gambar 3. Produksi Gas $\mathrm{CO}_{2}$ di Outlet

Adanya peningkatan konsentrasi pada pengujian hari ke-26 disebabkan karena pengambilan sampel gas metana yang keluar dari outlet dilakukan dengan cara dihisap menggunakan gas pump. Penghisapan ini dilakukan dari hari ke-26 hingga hari ke-30. Tujuan dilakukannya sampling dengan cara dihisap ini adalah untuk melihat berapa banyak metana yang masih terdapat di dalam reaktor setelah pengaliran gas dilakukan. Setelah dihisap, gas metana menunjukkan kenaikan konsentrasi. Kenaikan konsentrasi gas metana pada setiap outlet reaktor ini kemungkinan disebabkan karena perbedaan nilai bed true residence time setiap reaktor (Persamaan 1) yang ditampilkan pada Tabel 4.

Saat melakukan penghisapan dengan menggunakan air gas pump, reaktor yang menunjukkan kenaikan konsentrasi gas metana berturut-turut dari konsentrasi tertinggi adalah R1, R2, R4, dan R3. Konsentrasi yang tinggi pada masingmasing reaktor ini dapat terjadi karena masing-masing reaktor memiliki nilai true residence time yang berbeda-beda. True residence time merupakan waktu aktual dimana proses oksidasi terjadi dan merupakan fungsi dari porositas media, sehingga media yang tingkat pemadatannya lebih rendah memiliki nilai true residence time yang lebih singkat juga.

Tabel 4. Bed true residence time setiap reaktor

\begin{tabular}{ccc}
\hline Reaktor & $\begin{array}{c}\text { Bed True } \\
\text { Residence Time } \\
(\tau)\end{array}$ & $\begin{array}{c}\text { Rata-rata konsentrasi } \mathrm{CH}_{4} \\
\text { dengan perlakuan hisap } \\
\text { Hari-26 hingga Hari-30 }\end{array}$ \\
\hline $1\left(750 \mathrm{~kg} / \mathrm{m}^{3}\right)$ & $3 \mathrm{jam} 40 \mathrm{mnt}$ & $11,92 \mathrm{~g} / \mathrm{m}^{3}$ \\
$2\left(800 \mathrm{~kg} / \mathrm{m}^{3}\right)$ & $3 \mathrm{jam} 54 \mathrm{mnt}$ & $6,06 \mathrm{~g} / \mathrm{m}^{3}$ \\
$3\left(850 \mathrm{~kg} / \mathrm{m}^{3}\right)$ & $4 \mathrm{jam} 8,4 \mathrm{mnt}$ & $1,10 \mathrm{~g} / \mathrm{m}^{3}$ \\
$4\left(900 \mathrm{~kg} / \mathrm{m}^{3}\right)$ & $4 \mathrm{jam} 23,4 \mathrm{mnt}$ & $3,96 \mathrm{~g} / \mathrm{m}^{3}$ \\
\hline
\end{tabular}

Rendahnya konsentrasi metana sejak awal pengujian pada R2, R3, dan R4 tetap memungkinkan terjadinya pengurangan konsentrasi gas metana pada tingkat pemadatan yang semakin tinggi (Tabel 5). Hal ini terlihat konsisten pada rata-rata konsentrasi gas metana baik selama 35 hari (termasuk perlakuan pompa atau hisap) maupun pengukuran konsentrasi gas metana tanpa perlakuan hisap kecuali pada reaktor 2.

Terjadinya proses oksidasi juga dapat dilihat dari besaran produksi $\mathrm{CO}_{2}$. Berdasarkan Persamaan 5, degradasi gas metana oleh mikroorganisme pada kompos akan diiringi dengan adanya produksi gas $\mathrm{CO}_{2}$ dari hasil reaksi tersebut.

$\mathrm{CH}_{4}+\mathrm{O}_{2} \rightarrow \mathrm{xCO}_{2}+\mathrm{yH}_{2} \mathrm{O}+\mathrm{z}$ biomasa bakteri

Produksi $\mathrm{CO}_{2}$ pada $\mathrm{R} 4$ berfluktuasi dan menunjukkan kecenderungan kenaikan produksi selama penelitian dilakukan (Gambar 3). Mayoritas produksi $\mathrm{CO}_{2}$ untuk $\mathrm{R} 1$, R2, dan R3 menunjukkan nilai negatif mengindikasikan kondisi biofilter dimana karbon yang ada didalam kontaminan bergabung menjadi biomassa yang sebenarnya merupakan organisme yang mati dan dikonsumsi oleh organisme lainnya (Devinny dkk., 1999).

Selama proses degradasi metana, tidak hanya gas $\mathrm{CO}_{2}$ yang dihasilkan, namun terjadi juga proliferasi mikroorganisme (Persamaan 5). Pada R1, R2, dan R3 ini memiliki tingkat pertumbuhan mikroorganisme yang lebih tinggi, sedikit gas $\mathrm{CO}_{2}$ 
Reaktor, Vol. 15 No. 2, Oktober 2014, Hal. 117-125

Tabel 5. Rata-rata konsentrasi gas metana setiap reaktor

\begin{tabular}{cccc}
\hline $\begin{array}{c}\text { Reaktor } \\
(\mathrm{R})\end{array}$ & $\begin{array}{c}\text { Kepadatan kompos } \\
\left(\mathrm{kg} / \mathrm{m}^{3}\right)\end{array}$ & $\begin{array}{c}\text { Rata-rata konsentrasi } \\
(\text { selama 35 hari })\left(\mathrm{g} / \mathrm{m}^{3}\right)\end{array}$ & $\begin{array}{c}\text { Rata-rata konsentrasi (31 hari tanpa } \\
\text { perlakuan hisap) }(\mathrm{g} / \mathrm{m} 3)\end{array}$ \\
\hline 1 & 750 & $6,81 \pm 6,87$ & $5,72 \pm 6,80$ \\
2 & 800 & $1,86 \pm 4,59$ & $0,96 \pm 3,02$ \\
3 & 850 & $1,02 \pm 3,27$ & $1,00 \pm 3,61$ \\
4 & 900 & $0,74 \pm 1,76$ & $0,05 \pm 0,09$ \\
\hline
\end{tabular}

yang dihasilkan dan produksi lindi yang lebih banyak. Produksi $\mathrm{CO}_{2}$ yang tinggi dan lindi yang sedikit, menunjukkan bahwa kemungkinan terjadi proses respirasi lebih tinggi dibandingkan dengan proliferasi mikroorganisme. Proliferasi mikroorganisme semakin menurun pada R4 ini sehingga potensi terjadinya penyumbatan pada pori dapat dihindari. Secara umum efisiensi penyisihan gas metana ditampilkan pada Gambar 4.

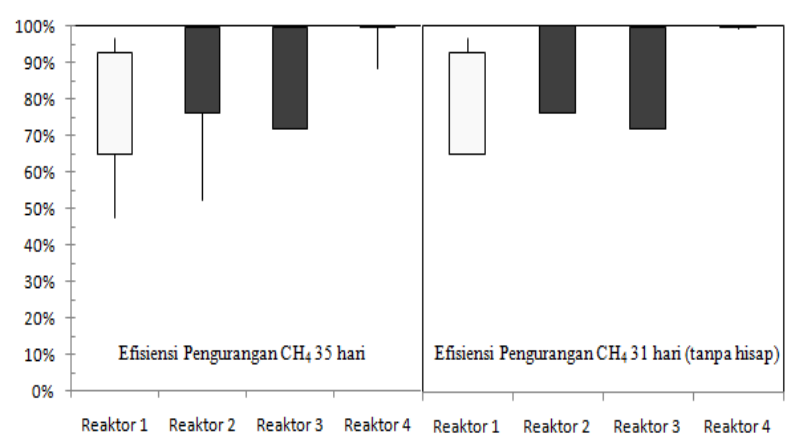

Gambar 4. Efisiensi penyisihan gas metana

Persentase penyisihan metana pada R1, R2, R3, dan R4 berada pada rentang 47,71 $\pm 12,4 \%$ hingga $96,63 \pm 12,4 \%$. R1 dengan tingkat pemadatannya lebih kecil dibanding reaktor lainnya mempunyai variasi persen penyisihan yang besar dalam mengoksidasi gas metana, namun efisiensi penyisihan terkecil dibandingkan reaktor lainnya. Hal ini terjadi baik dengan ditambahkannya nilai efisiensi pengurangan gas metana melalui sampling dengan pemompaan/hisap pada reaktor (efisiensi pengurangan $\mathrm{CH}_{4}$ selama 35 hari) maupun tanpa adanya pemompaan (nilai efisiensi pengurangan $\mathrm{CH}_{4}$ selama 31 hari). Kecenderungan persentase penyisihan metana terbanyak R1 berada pada kisaran 65-93\% baik dengan ataupun tanpa perlakuan hisap, dan ratarata penyisihan selama 35 hari sebesar $87,2 \pm 12,4 \%$ dan rata-rata tanpa perlakuan hisap sebesar $89,21 \pm 7,81 \%$.

R2 memiliki persentase penyisihan gas metana yang lebih besar dibandingkan dengan R1 dengan persentase penyisihan yang cenderung mendekati
$100 \%$, yaitu dengan persentase terbanyak dalam rentang antara $76 \%$ hingga $100 \%$. Persentase penyisihan terendah pada R2 yaitu $52,27 \pm 0,12 \%$ dan persentase penyisihan tertinggi sebesar $100 \pm 0,12 \%$. Dari penelitian yang dilakukan, didapatkan rata-rata persentase penyisihan gas metana pada R2 sebesar 95 $\pm 0,12 \%$ selama 35 hari pengujian. Rata-rata efisiensi pengurangan $\mathrm{CH}_{4}$ pada Reaktor 2 tanpa perlakuan hisap lebih besar dibanding reaktor 3, namun perbedaan nilainya tidak terlalu signifikan. R3 memiliki persentase penyisihan gas metana yang cenderung lebih seragam dibandingkan R1 dan R2 selama 35 hari pengujian. R3 memiliki persentase penyisihan terbanyak dalam rentang antara $72 \%$ hingga $100 \%$, dengan persentase penyisihan terendah $71,88 \pm 0,06 \%$ dan persentase penyisihan tertinggi sebesar $100 \pm 0,06 \%$. Rata-rata persentase penyisihan gas metana pada Reaktor 3 ini adalah sebesar 97,64 \pm $0,06 \%$ untuk pengujian termasuk perlakuan hisap dan $97,92 \pm 0,07 \%$ tanpa perlakuan hisap. Nilai efisiensi baik ataupun tanpa perlakuan hisap tidak terlalu berbeda secara signifikan, sehingga pengaruh pemadatan dapat dianalisis dari pengujian yang telah dilakukan selama 35 hari termasuk dengan adanya perlakuan hisap.

Berbeda dengan reaktor lainnya, R4 memiliki persentase penyisihan gas metana yang cenderung seragam dan lebih banyak yang mencapai $100 \%$. Persentase penyisihan gas metana pada R4 ini sudah mencapai $100 \%$ pada hari pertama pengujian. R4 memiliki persentase penyisihan terbanyak dalam rentang antara $96 \%$ hingga $100 \%$, dengan persentase penyisihan terendah $88,47 \pm 0,03 \%$ dan persentase penyisihan tertinggi sebesar $100 \pm 0,03 \%$. Rata-rata persentase penyisihan gas metana pada Reaktor 4 ini adalah sebesar 98,31 \pm 0,03\%. Kapasitas eliminasi gas metana dalam reaktor ditampilkan pada Tabel 6 .

Kapasitas eliminasi setiap reaktor memiliki nilai maksimum yaitu $22,9 \mathrm{~g} / \mathrm{m}^{3} / \mathrm{jam}$ untuk R1 sebesar $24,02 \quad\left(\mathrm{~g} / \mathrm{m}^{3} / \mathrm{jam}\right)$ untuk R2 sebesar 23,99 ( $\left.\mathrm{g} / \mathrm{m}^{3} / \mathrm{jam}\right)$ untuk R3 sebesar 23,99 $\left(\mathrm{g} / \mathrm{m}^{3} / \mathrm{jam}\right)$, dan $24,03\left(\mathrm{~g} / \mathrm{m}^{3} / \mathrm{jam}\right)$ untuk R4. Berdasarkan hasil kapasitas eliminasi (Tabel 5), terlihat jelas bahwa

Tabel 6. Kapasitas eliminasi gas metana setiap reaktor

\begin{tabular}{ccccc}
\hline \multicolumn{5}{c}{ Kapasitas eliminasi $\left(\mathrm{g} / \mathrm{m}^{3} / \mathrm{jam}\right)$} \\
\hline \multirow{2}{*}{ Reaktor } & $\begin{array}{c}\text { Rata-rata } \\
(35 \text { hari) }\end{array}$ & $\begin{array}{c}\text { Rata-rata } \\
\text { (tanpa perlakuan hisap) }\end{array}$ & $\begin{array}{c}\text { Nilai } \\
\text { maks }\end{array}$ & Nilai min \\
\hline 1 & $12,22 \pm 3,98$ & $12,85 \pm 3,82$ & 22,90 & 4,69 \\
2 & $13,66 \pm 4,77$ & $14,24 \pm 4,68$ & 24,02 & 5,14 \\
3 & $13,90 \pm 4,43$ & $14,23 \pm 4,70$ & 23,99 & 8,47 \\
4 & $13,98 \pm 4,32$ & $14,50 \pm 4,55$ & 24,03 & 8,47 \\
\hline
\end{tabular}


tingkat pemadatan yang berbeda-beda dapat menyebabkan kapasitas eliminasi kompos dalam mereduksi gas metana juga berbeda-beda. Semakin tinggi tingkat pemadatan, semakin besar kapasitas eliminasi gas metananya. Perbedan dengan ataupun tanpa perlakuan hisap tidak terlalu signifikan sehingga nilai yang diambil adalah nilai pengujian selama 35 hari termasuk adanya perlakuan penghisapan. Pada penelitian ini didapatkan bahwa tingginya tingkat pemadatan pada kompos dapat membuat kapasitas eliminasi gas metana juga besar.

\section{KESIMPULAN}

Pemeriksaan karakteristik fisik, kimia, dan biologis kompos produksi unit pengolah sampah Depok menunjukkan bahwa kompos berpotensi dijadikan sebagai media biocover setelah terlebih dahulu dilakukan proses pengolahan pendahuluan. Pemadatan berpengaruh terhadap terhadap efektivitas kompos dalam mereduksi gas metana dalam rentang penurunan yang bervariasi. Kompos dengan tingkat pemadatan $900 \mathrm{~kg} / \mathrm{m}^{3}$ (R4) memiliki efisiensi 98,31 \pm $0,04 \%$ yang merupakan rentang kecenderungan persentase efisiensi tertinggi di antara reaktor lainnya, yaitu 96-100\%, dan kapasitas eliminasi rata-rata sebesar 13,98 $\pm 4,32 \mathrm{~g} / \mathrm{m}^{3} / \mathrm{jam}$. Tingkat pemadatan $900 \mathrm{~kg} / \mathrm{m}^{3}$ sangat disarankan dalam aplikasi kompos sebagai media biocover, karena memiliki potensi pengurangan gas metana terbesar serta potensi clogging yang lebih rendah. Penelitian lanjutan dengan aplikasi di lapangan diperlukan untuk memberikan konfirmasi pada hasil yang diperoleh dalam skala laboratorium.

\section{UCAPAN TERIMA KASIH}

Penulis mengucapkan terima kasih kepada Direktorat Jendral Pendidikan Tinggi Republik Indonesia yang telah mendukung pendanaan penelitian ini. Juga kepada Prof. Lahl dan Prof. Jäger dari University of Darmstadt, Jerman atas izin penggunaan fasilitas laboratorium dan diskusi mendalam tentang sampah Indonesia.

\section{DAFTAR PUSTAKA}

Abichou, T., Mahieu, K., Yuan, L., Chanton, J., and Hater, G., (2009), Effect of compost biocovers on gas flow and methane oxidation in a landfill cover, J. of Waste Mngmt., pp. 1595-1601.

American Public Health Association, American Water Works Association, Water Environment Federation, Rice, E.W.(Ed.), Baird, R.B. (Ed.), Eaton, A.D. (Ed.), Clesceri, L.S. (Ed.). (2012), Standard Methods for the Examination of Water and Wastewater, USA: American Water Works Assn; 22 ed.

Badan Standardisasi Nasional, (2004), Spesifikasi Kompos dari Sampah Organik Domestik SNI No.197030-2004, Jakarta.
Bodelier, P. and Laanbroek, H., (2004), Nitrogen as a regulatory factor of methane oxidation in soils and sediments, FEMS Microbiol. Ecol, pp. 265-277.

Burton, S. and Watson-Craik, I., (1998), Ammonia and nitrogen fluxes in landfill sites: applicability to sustainable lanfillling, Waste Mngmt. and Res., 16, pp.41-53.

Damanhuri, E., Ismaria, R., dan Padmi, T., (2006), Pedoman Pengoperasian dan Pemeliharaan TPA Sistem Controlled Landfill dan Sanitary Landfill, Bandung: Departemen PU Direktorat Jenderal Cipta Karya.

Devinny, J.S., Deshusses, M.A., and Webster, T.S., (1999), Biofiltration for Air Pollution Control, USA: CRC Press LLC.

Dinas Kebersihan dan Pertamanan Kota Depok, (2012), Mengenal lebih dekat TPA di Cipayung Kota Depok,Workshop: Biological Treatment for Municipal Solid Waste in Indonesia, Depok: Dinas Kebersihan dan Pertamanan Kota Depok.

Figueroa, R., (1993), Methane oxidation in landfill top soils, Proc. of Fourth International Waste Management and Landfill Symposium, Sardinia, Forte Village-S. Margherita di Pula (CA), 11-15 Oktober 1993.

Huber-Humer, S., Roder, and Lechner, P., (2009), Approaches to assess biocover performance on landfill, Waste Mngmt., 29, pp. 2092-2104.

Humer, M. and Lechner, P., (2001), Microbial methane oxidation for the reduction of landfill gas emissions, The Journal of Solid Waste Tech. and Mngmt., pp. 146-151.

Intergovernmental Panel on Climate Change (IPCC), (2000), IPCC Good Practice Guidance and Uncertainty Management In National Greenhouse Gas Inventories, (Ishigaki, T., Hirata, O., Oda, T.,and Wangyao, Eds.) Retrieved 2014.

Kumar, T.P., Rahul, Mathur Anil Kumar, M.A., Chandrajit, B., (2011), Biofiltration of Volatile Organic Compounds (VOCs): a review, Rsch. J. of Chem. Sci., 1(8), pp. 83-92.

Mosafid, M.E., Shank, C., Imhoff, P.T., and Yazdani, R., (2012), Gas transport properties of compostwoodchip and green waste for landfill,Chem. Eng. J., 191, pp. 314-325.

Mor, S., De Visscher, A., Revindra, K., Dahiya, R., Chandra, A., and Van Cleemput, O., (2006), Induction of enhanced methane oxidation in compost: Temperature and moisture response, Waste Mngmt., pp. 26, 381-388. 
Ng, T. and Kristanto, G.A., (2013), Potency of Methane gas Emission From Waste Sector In Depok, Indonesia, Symposium OnCoastal Cities, Marine Resources, and Climate Change: Sustainability and Climate Change, Depok, 5 July 2013.

Permen PU No. 3, (2013), Penyelenggaraan Prasarana dan Sarana Persampahan dalam Penanganan Sampah Rumah Tangga dan Sampah Sejenis Sampah Rumah Tangga.

Philopoulos, A., Ruck, J., McCartney, D., and Felske, C., (2009), A laboratory-scale comparison of compost and sand - compost - perlite as methane-oxidizing biofilter media, Waste Management Resource, 27, pp. 138-146.

Scheutz, C., Kjeldsen, P., Bogner, J., De Visscher, A., Gebert, J., and Hilger, H., (2009), Microbial methane oxidation processes and technologies for mitigation of landfill gas emissions, Waste Mngmt. Rsch., 27, pp. 409-455.

Streese, J. and Stegmann, R., (2003), Microbial oxidation of methane from old landfills in biofilters, Waste Management, 23(7), pp. 573-580.

Tchobanoglous, G. and Kreith, F., (2002), Handbook of Solid Waste Management, USA: McGraw-Hill.

Tchobanoglous, G., Theisen, H., and Vigil, S., (1993), Integrated Solid Waste Management, United States: McGraw-Hill, Inc. 